Герасимчук В.Г. доктор економічних наук, професор ORCID ID: 0000-0001-9357-8925

\author{
Лі Іму (КНР) \\ ORCID ID: 0000-0001-5429-9720
}

Національний технічний університет Украӥни «Київський політехнічний інститут імені Ігоря Сікорського»

\title{
РЕФОРМУВАННЯ ЕКОНОМІКИ КИТАЮ: ЕТАПИ, РЕЗУЛЬТАТИ, ПЕРСПЕКТИВИ
}

\section{REFORMING CHINA'S ECONOMY: STEPS, RESULTS, PERSPECTIVES}

Досліджується прочес поступового переходу лідируючих позицій у світовій економічній системі від країн групи «G7» до «E7» на чолі з Китаєм відповідно до законів циклічного, "спіралеподібного» розвитку цивілізації. Розглянуто генезис і основні принципи конфуціанства як етико-політичного $і$ філософського вчення, щзо базується на трьох складових: сочіальна гармонія, людяність і ритуал. Розкрито ключові фактори успішного $і$ стабільного розвитку економіки Китаю: масштабне, продуктивне та організоване землеробство, наукові відкриття, ремесла, виробництво продукиії на внутрішній $i$ зовнішній ринок, торгівля, розвиток міст, кредитно-банківська система, сильна центральна влада $i$ податкова система. Вивчено особливості процесу модерізаціі економіки, вирішення політичних, сочіальних і екологічних проблем КНР з використанням традииійних иінностей конфуціанства в період 1949-2018рр. Надано критичну оиінку економічній політиці КПК в періоди «великого стрибка», «культурної революції», а також «чотирьох модернізацій». Представлені теоретико-методологічні підходи до формування та реалізаиії основних етапів стратегії розвитку Китаю на період до 2050р. в умовах викликів глобалізації при дотриманні принщипу стабільності в русі. Проведено аналіз стану торгово-економічних відносин між Україною та Китаєм, розроблені пропозиціі щзодо перспектив їх подальшого розвитку на рівноправній та взаємовигідній основі. Звернуто увагу на основні напрямки китайських інтересів на ринку Украӥни: сільське господарство, інфраструктура, енергетика, освіта, наука і техніка. Розкрито переваги та загрози створення зони вільної торгівлі «Китай-Украӥна» з використанням методології SWOT-аналізу. Наголошується на необхідності розробки запобіжних заходів зі строни держави щуодо максимального захисту інтересів вітчизняних товаровиробників в торгівлі з більш сильним і більш досвідченим партнером. Варто при изьому враховувати досвід функиіонування зони вільної торгівлі «Україна - СС».

Ключові слова: глобалізація, якість життя, конфуціанство, лідерство, стабільність, стратегія, економічні реформи

The process of gradual transition of leading positions in the global economic system from the countries of the group "G7" to "E7" led by China is studied in accordance with the laws of cyclic, "spiral" development of civilization. The genesis and basic principles of Confucianism as an ethical-political and philosophical doctrine are considered, which is based on three components: social harmony, humanity and ritual. The key factors of the successful and stable development of the Chinese economy are revealed: large-scale, productive and organized 
agriculture, scientific discoveries, crafts, production of products on the domestic and foreign markets, trade, urban development, credit and banking system, strong central government and the tax system. The features of the process of modernization of the economy, solution of the political, social and environmental problems of the PRC with the use of traditional values of Confucianism during the period 1949-2018 were studied. The critical assessment of the CCP's economic policies during the "big jump", "cultural revolution", and "four modernizations" was provided. The theoretical and methodological approaches to the formation and realization of the main stages of the development strategy of China for the period up to 2050 under the conditions of the challenges of globalization while respecting the principle of stability in the movement are presented. The analysis of the state of trade and economic relations between Ukraine and China was made; proposals on the prospects for their further development on the equal and mutually beneficial basis were developed. The attention is focused on the main directions of Chinese interests in the Ukrainian market: agriculture, infrastructure, energy, education, science and technology. The advantages and threats of creation of the China-Ukraine free trade zone with the use of SWOT-analysis methodology are revealed. It is emphasized that it is necessary to develop preventive measures in order to maximally protect the interests of domestic commodity producers in trade with a stronger and more experienced partner. It is worth taking into account the experience of the functioning of the FTD Ukraine-EU.

Keywords: Confucianism, economic reforms, globalization, leadership, quality of life, stability, strategy

Вступ. "Paulatim summa petuntur (Лат.). - Вершини досягаються поступово". Серед вручених протягом 1969-2017pp. нобелівських премій 3 економіки лише одного разу (1979p.) вона присвоювалася за новаторські дослідження економічного розвитку по відношенню до проблем країн, що розвиваються. Нагромаджені проблеми у цій численній групі держав (близько $4 / 5$ всіх країн світу, понад 77\% жителів планети) 3 якихось причин не знаходяться в сфері інтересів іменитих учених-економістів. Можлива причина «неуважності» до даної проблематики полягає в небажанні визнавати, що за законами «спіралеподібного», циклічного розвитку соціально-економічних процесів на зміну лідерства в світовій економіці групи розвинених країн «G7» поступово приходять країни «Е7».

Дж. О'Ніл, аналітик банку «Goldman Sachs», передбачав ще у 2009p., що до 2027p. країни БРІК обійдуть країни «G7» за сукупним ВВП [1]. Експерти PWC в 2014p. також передрікали «G7» втрату лідерських позицій у 2027p. Реалії свідчать про можливий зсув цих термінів на більш ранній період. Дж. Хоксуорт, головний економіст $\mathrm{PwC}$, стверджує: «Частка економіки 7 найбільших країн з економікою, що розвивається, у світовому ВВП може скласти близько $50 \%$, в той час, як частка країн «Великої сімки» зменшиться до близько 20\%» [2].

Лідируюча в групі країн «Е7» економіка КНР зараз займає другу позицію в світовому рейтингу за номінальним ВВП. Очікується, що в 2027p. економіка Китаю випередить США і стане найпотужнішою у світі. У 2014p. Китай вже обійшов США за показником ВВП (ПКС). Таким чином, лідерство у світовій господарській системі поступово переходить до групи великих країн 3 
економікою, що розвивається, на чолі з КНР. У вивченні цього історичного, політичного, соціального і економічного «феномена» XXI століття і полягає актуальність дослідження.

Постановка завдання. «Expressum facit cessare tacitum (Лam.). Грамотне формулювання усуває тлумачення». Мета дослідження полягає у встановленні закономірностей успіху при проведенні економічних реформ в Китаї на основі конфуціанської філософії та їх вплив на зміни, що відбуваються у світовій господарській системі.

Для реалізації поставленої мети сформульовані наступні завдання:

- визначити генезис і розглянути основні принципи конфуціанства як етико-політичного і філософського вчення; Китаї;

- охарактеризувати відмітні риси становлення економічних відносин в

- дослідити процес модерізаціі економіки, вирішення соціальних i екологічних проблем КНР 3 використанням традиційних цінностей конфуціанства;

- вивчити теоретико-методологічні підходи до формування та реалізації стратегії розвитку КНР на період до 2050 р.;

- здійснити аналіз стану торгово-економічних відносин між Україною та Китаєм, внести пропозиції щодо їх подальшого розвитку.

Об'єктом дослідження є процес модернізації економіки КНР. Предмет дослідження полягає у вивченні впливу конфуціанського вчення на соціальноекономічні перетворення в Китаї в ретроспективі і як прогресуючого лідера здійснюваних змін у світовій економіці.

Методологія. "Вчення без роздумів марно, але й роздуми без вчення небезпечні» (Конфуцій). Теоретичною базою виконаного дослідження слугують ключові положення економічної науки, концептуальні підходи до вивчення проблем геополітики, розвитку світової господарської системи, національних економік, циклічності розвитку економічних систем, а також праці відомих вчених-економістів. Серед вчених-синологів відзначимо публікації А.П. Дев'ятова, Л.П. Делюсина, А.І. Кобзєва, Н.І. Конрада, В.В. Малявіна, Л.С. Переломова, М.Л.Тітаренко.

Методологічною основою виконаної роботи є загальнонаукові методи (емпіричний метод, аналізу i синтезу, порівняння, екстраполяції, систематизації, логічного аналізу), а також спеціальні методи (цивілізаційного розвитку, історичний i компаративістський, функціональний та інституціональний, програмно-цільовий).

Результати дослідження. Генезис і основні принципи конфуціанства як етико-політичного і філософського вчення. "Я передаю, а не складаю. $Я$ вірю в старовину $і$ люблю ї̈»(Конфуиій). Однією з найдавніших у світі $\epsilon$ китайська цивілізація. За твердженням шотландського філософа і соціолога А. Фергюсона, цивілізацією можна назвати стадію суспільного розвитку, що 
характеризується наявністю міст, соціальних класів, писемності, розвитком землеробства і ремесел, а також раціоналізацією мислення [3].

Кожна 3 цивілізацій формувалася в локалізоване в часі і просторі суспільство. Локальні цивілізації були цілісними системами. Вони представляли собою комплекс економічної, політичної, соціальної і духовної підсистем, які розвивалися за законами вітальних циклів (зародження, розвиток, розквіт і згасання). Не всім цивілізаціям довелося пройти усі названі стадії. У деяких з них цикл переривався в силу природних катастроф, сутичок з іншими культурами, або з інших причин.

Крім цього, певні цивілізації (індуїстська, синська, японська, буддистська і православна) мають свої стрижневі, зазвичай, багаті країни. Не можна не підкреслити, що світовий духовний, ідеологічний простір займають саме багаті країни. Цивілізації, що мають стрижневі країни, зазвичай, відрізняються своєю стабільністю в розвитку. До них відноситься й китайська цивілізація.

К. Ясперс зазначає, що вісь світової історії відноситься до часів близько 500 років до н. е. «У цей час відбувається багато незвичайного. У Китаї жили тоді Конфуцій і Лао-цзи, виникли всі напрямки китайської філософії, мислили Мо-цзи, Чжуан-цзи, Ле-цзи і безліч інших мудреців. В Індії виникли Упанішади, жив Будда; у філософії - в Індії, як і в Китаї - були розглянуті всі можливості філософського осягнення дійсності, аж до скептицизму, до матеріалізму, софістики і нігілізму; в Ірані Заратустра вчив про світ, де відбувається боротьба добра зі злом; в Палестині виступали пророки Ілля, Ісайя, Єремія і Второісайя; в Греції - це час Гомера, філософів Парменіда, Геракліта, Платона, трагіків, Фукідіда і Архімеда. Все те, що пов'язано з цими іменами, виникло майже одночасно протягом небагатьох століть у Китаї, Індії і на Заході незалежно один від одного» [4].

Особливо шанують і зберігають традиції минулого в Китаї. Поряд 3 даосизмом, буддизмом та іншими найдавнішими віруваннями чільну роль протягом понад двох тисячоліть продовжує займати конфуціанство. Його засновником $\epsilon$ великий китайський філософ і педагог останнього періоду «Воюючих царств» Конфуцій (551- 479 до н.е.).

Згідно з ідеологією конфуціанства, необхідно дбайливо ставитися до того, що було накопичено в минулому, пропагувати, розвивати і поглиблювати все краще, оскільки саме в минулому перебуває ключ до сьогодення та майбуття. На переконання Кофуція, людям необхідно слідувати шляхом природи, бо головною метою в житті людини є досягнення гармонії з іншими людьми і 3 навколишнім світом. Ключові концепції конфуціанства відображаються в трьох складових: соціальна гармонія, людяність і ритуал. Принцип суспільної гармонії полягає в тому, що кожен повинен слідувати згідно зі своїм призначенням [5].

Учитель мріяв про мир і єднання всього народу. Ним була висунута ідея згуртування членів сім'ї, колективу, об'єднання держави і громадян. Сенс життя кожної людини полягає в дотриманні високих моральних ідеалів, 
головним 3 яких виступає «шляхетний чоловік». Найважливішими принципами навчання $є$ : шанобливість до батьків i старших; гуманність i людяність; справедливість, борг і обов'язок; норми моралі і ритуал; чеснота, моральність і мораль, етика; гармонія, дружба і мир; золота середина; освіта та виховання.

Управляти державою повинні люди 3 високими моральними якостями. Правителю необхідно пам'ятати про те, що закони в державі грунтуються не на суворості покарання, а на чеснотах та дотриманні ритуалів для підтримки громадського порядку. На думку Конфуція, вищою метою управління повинні бути інтереси народу. При цьому будь-який «молодший» в сім'ї, колективі, державі зобов'язаний беззаперечно підкорятися волі «старшого». Маючи в наявності внутрішній механізм самопізнання, саморозвитку і самокритики, конфуціанство розвивається відповідно до нових умов суспільства.

Відмінні риси становлення економічних відносин в Китаї. «Обдумай, чи правильним і можливим є те, щуо ти обіияєщ, бо обіиянка - $е$ борг» (Конфуцій). Процес становлення економічних відносин нерозривно пов'язаний 3 історичним розвитком державності Китаю. Охарактеризуємо найбільш важливі фрагменти становлення економічних відносин в Китаї, що складаються в процесі суспільного виробництва, розподілу, обміну та споживання. Економіка Стародавнього Китаю 3 ii злетами i падіннями упродовж тривалої історії визначила свою особливу комерційну культуру. Великі імперії старовини зростали, перш за все, за рахунок таких секторів економіки, як землеробство, ремесла і торгівля.

Китай дав світу низку наукових відкриттів і технічних винаходів, що здійснили великий вплив на розвиток науки, техніки та економіки. Результатом розвитку гончарної справи став винахід в Китаї порцеляни. Китайці першими стали займатися шовководством. Саме цим пояснюється поява Великого Шовкового Шляху. У 70г. нової ери почалося будівництво «Великого каналу». Найбільш грандіозним у всьому Стародавньому світі стало спорудження Великої Китайської стіни. В середині II тисячоліття до нової ери виникає писемність. Великих успіхів досягла китайська медицина. Влада підтримували і заохочували розвиток наукових знань. У першому китайському університеті, створеному в II столітті до н. е. в Лояні, навчалося 50 студентів. До початку I століття н. Е. тут вже навчалося близько 3000 чоловік. У Китаї виникла система державних іспитів.

Зростання обсягу надлишкового продукту призвів до появи спочатку мінової торгівлі, а потім і грошової. У якості грошей використовувалися черепашки, нефрит, кістки, мідь і т.д. Згодом з'явилися металеві гроші. Приблизно у 800p. стали друкувати грошові знаки 3 паперу. Держава регламентувала торгівлю, встановлювалися якість і ціни товарів. Ринки були строго розділені на квартали за видами товарів. За організацію і контроль роботи ринків відповідали особливі чиновники. Ринкова торгівля обкладалася державними зборами. 3 підвищенням грошового обороту в країні був 
заснований найперший в світі адміністративний і ощадний банк «Управління Jiaozi».

Китай вів великоосяжну торгівлю з багатьма країнами. Китайські купці об'єднувалися в купецькі гільдії. Їх каравани доставляли товари в Середню Азію, Сирію, Римську імперію, Корею, держави Індокитайского півострова. Зовнішня торгівля виступала важливим джерелом доходів, як державної скарбниці, так і розвиненого шару купців.

У стародавньому Китаї купці використовували різні способи підвищення ефективності продажів. Найпопулярнішим методом була реклама. Під музику i танці купці ритмічно i дружно закликали покупців купити їх товар. Ефективним методом було створення рекламних вивісок. Вивіски виготовляються з паперу, шовку або дошки. На фасадах магазинів можна було зустріти ліхтарі і накреслені рекламні символи. Каліграфічна друкована реклама з'явилися за часів династії Сун (960-1279pp.), тобто на 300 років раніше, ніж в Свропі.

Купці брали участь у створенні академій, шкіл і екзаменаційних центрів. Купців поважали за вірність i чесність, які $є$ двома найважливішими достоїнствами при веденні торгівлі. Землеробство, ремесла і купецтво дали потужний поштовх економічному розвитку держави.

Дослідження процесу модерізаціі економіки КНР 3 використанням традиційних цінностей конфуціанства. "Дорогоцінний камінь не можна відполірувати без тертя. Також і людина не може стати успішною без достатньої кількості важких спроб» (Конфуиій). У 1911р. в Китаї відбулася буржуазно-демократична революція. Незабаром утворилася конституційна республіка під керівництвом Сунь Ятсена. Протягом наступних років відбувалася боротьба за владу. Китай пройшов низку кривавих потрясінь: громадянські війни, Другу Світову війну.

1 жовтня 1949p. Мао Цзедун проголосив утворення Китайської Народної Республіки. Почався етап будівництва соціалізму. У період першої п'ятирічки (1953-1957pp.) Провідну роль у національній економіці відігравала суспільна власність на засоби виробництва, увага акцентувалася на розвитку важкої промисловості, прискореними темпами відбувалася колективізація.

Наступним етапом економічної політики Комуністичної партії Китаю (КПК) став «Великий стрибок» (1958-1965pр.). Економіка розвивається переважно на екстенсивної основі. Політика «Великого стрибка», однією 3 цілей якого стало наздогнати Англію 3 виробництва чавуну на душу населення, призвело китайський народ до голоду. Протягом 1966-1976pp. здійснювалася «Культурна революція». Мало місце гоніння за інтелігенцією, діячів культури відправляють «на перевиховання» в села і віддалені райони.

Після відходу з політичної арени Мао Цзедуна владу над діяльністю КПК бере під свій контроль Ден Сяопін. Переломний момент у політичному і економічному розвитку країни настав після виступу Ден Сяопіна $з$ програмою змін на III пленумі ЦК КПК ХІ скликання 18-22 грудня 1978p. На пленумі був 
узагальнений досвід попереднього періоду в будівництві соціалізму i засуджені помилки, допущені, головним чином, під час «культурної революції».

Центр тяжіння партійної роботи перенесено на здійснення модернізації. Була оголошена і затверджена нова політика «реформ і відкритості». Реформи спрямовувалися на приведення виробничих відносин у відповідність із завданнями розвитку продуктивних сил. Політика «відкритості» була покликана включити КНР в процес глобалізації економіки, активно залучати закордонні капітали, використовувати досягнення науки i техніки, управлінський досвід для підвищення світової конкурентоспроможності Китаю.

Базисом для практичної розробки реформаторских ідей Ден Сяопіна став затверджений ще у січні 1975p. курс «чотирьох модернізацій» - в сільському господарстві, промисловості, армії, науці і техніці. Ден Сяопін сформував ключові теоретичні i програмні положення стратегії реформ. Шлях модернізації - прискорене економічне зростання, якісне оновлення економіки і підвищення іiі ефективності на базі розвитку науково-технічного потенціалу [6]. Китаю вдалося стати «світовою майстернею», досягти успіхів в економіці шляхом зниження витрат на інновації, оновлення промисловості. КНР вдалося вирішити проблему прогодування численного населення та продовольчого дефіциту, підвищити грошові доходи селян.

Ден Сяопін відмовився від протиставлення плану і ринку, розглядаючи $\mathrm{i}$ те, i інше лише як засоби в руках держави для розвитку економіки. При формуванні ринкових відносин в Китаї спиралися на моральні принципи, згідно з якими збагачення повинно бути досягнуто чесною працею, а не обманом і грабунком. У процесі модернізації були вироблені три основних економічних гасла, що відповідають трьом основним етапам реформи.

На першому етапі (1978-1984pp.) висунуто гасло «планова економіка основа, ринкове регулювання - доповнення». Головна увага приділялася селу, в місті проводилися експерименти 3 розширення господарської діяльності підприємств, створювалися спеціальні економічні зони (СЕЗ). На другому етапі (1984-1991pp.) використовувалося гасло «планова товарна економіка». Центр тяжіння реформи перемістився з села в місто, державні підприємства стали основною ланкою модернізації. Особливу увагу при переході до ринку приділялося реформі цін [7]. На третьому етапі (1992-2002pр.) під гаслом «соціалістичної ринкової економіки» формувалася нова економічна система, спрямована на подальше розширення і розвиток ринку, створення нової системи управління підприємствами, а також формування ринкового механізму макрорегулювання і контролю з боку держави на новій основі.

3 2003p. почався четвертий етап реформи - етап вдосконалення соціалістичної ринкової економіки. Він включав в себе наступні елементи: реформу державних підприємств; створення комплексної системи ринків; поглиблення реформи систем розподілу і соціального забезпечення; створення 
механізму непрямого регулювання макроекономіки 3 проведенням реформи планової, банківської та податкової систем.

На відміну від шокової терапії китайська реформа здійснюється поступово і комплексно, кожна іiі ланка ретельно обговорюється, зважується. Як показав негативний «досвід» багатьох країн, за допомогою шокової терапії можна лише зруйнувати напрацьований механізм, але не можна швидко створити новий. В результаті країна скочується до хаосу, до втрати всього того, що накопичено багатьма поколіннями.

У 2012p. було оголошено, що в Китаї «встановлено соціалістичний лад 3 китайською специфікою». Економіка КНР протягом останніх трьох десятиліть постійно зростає. У 2016р. країна займала 2-е місце в світі за величиною номінального ВВП, 1-е - за обсягом валютних резервів, 2-е - за обсягом зовнішньої торгівлі. Китай на початку XXI століття став світовою індустріальної наддержавою.

Стан і перспективи розвитку торгово-економічних відносин між Китасм і Україною. "Коли шляхи неоднакові, не складають разом плани» (Конфуиій). Відкриття економіки Китаю означало розширення зв'язків 3 рештою світу, що знаходило відображення в збільшенні його частки у світовій торгівлі, глобальних ринках окремих товарів і потоках капіталу. Відкритість економіки КНР торкнулося і України [8].

Китай займає друге місце за обсягом товарообігу з Україною. Ситуація з торговим балансом у співпраці двох країн з 2003р. складається на користь китайського бізнесу (табл. 1).

У 2016p. 3 китайської сторони прозвучала пропозиція про створення зони вільної торгівлі (ЗВT) з Україною. SWOT-аналіз дає можливість розкрити перспективи розвитку подій після створення ЗВТ 3 їх позитивними очікуваннями і ризиками.

Таблиця 1 - Структура торгівлі товарами між Україною та Китаєм, 2002-2017pp., \$ млн.

\begin{tabular}{|l|c|c|c|c|c|c|c|c|}
\hline \multicolumn{1}{|c|}{ Роки } & 2002 & 2005 & 2010 & 2013 & 2014 & 2015 & 2016 & 2017 \\
\hline $\begin{array}{l}\text { Товаро- } \\
\text { обіг }\end{array}$ & 959,7 & 2521,6 & 5980,7 & 10137,4 & 8085,1 & 6170,1 & 6520,2 & 7686,5 \\
\hline Експорт & 700,0 & 711,2 & 1315,5 & 2691,2 & 2674,1 & 2399,1 & 1832,5 & 2039,4 \\
\hline Імпорт & 259,7 & 1810,4 & 4665,2 & 7446,2 & 5411,0 & 3771,0 & 4687,7 & 5647,1 \\
\hline Сальдо & 440,3 & $-1099,2$ & $-3349,7$ & $-4750,0$ & $-2736,9$ & $-1371,9$ & $-2855,2$ & $-3607,7$ \\
\hline
\end{tabular}

Примітка. Складено автором за даними Держстату Украӥни

Основні переваги ЗВТ: спрощення візового режиму, полегшення регуляції норм і законів, взаємної торгівлі; пожвавлення торгівлі товарами і послугами; збільшення обсягу інвестицій. Серед ризиків для України при створенні ЗВТ: можливе ускладнення просування експортних поставок української продукції на ринок КНР; більш висока конкурентоспроможність 
китайських товарів порівняно 3 українськими аналогами може витіснити вітчизняного товаровиробника 3 власного ринку; закриття вітчизняних підприємств, відтік висококваліфікованих кадрів за кордон.

Економічна експансія КНР пояснюється необхідністю вирішення цілого комплексу проблем, що накопичилися в Піднебесній. Зростання населення КНР i підвищення його добробуту, зменшення надбавки врожайності, перспектива виникнення дефіциту води, зміни клімату стали серйозними викликами для продовольчої безпеки країни. Серед методів вкладення капіталу в АПК практикується, зокрема, наступне: придбання землі (Австралія, Франція), ii оренда (Аргентина, Бразилія і Росія), надання сільськогосподарських машин і працівників в обмін на частину врожаю (Венесуела, Зімбабве).

Китай зацікавлений у розвитку транспортно-логістичної системи України, яка дозволить прискорити і здешевити вантажне і пасажирське сполучення КНР з країнами ЄС. Особливу увагу китайська сторона проявляє до розвитку портової інфраструктури. Китай зацікавлений в українських зернових, в першу чергу, - кукурудзі. Побудувавши власний термінал в порту, він скорочує витрати на логістику. У сфері енергетики китайці зацікавилися українськими ініціативами 3 будівництва сонячних електростанцій. Вони зможуть щорічно приносити дохід у розмірі 120-130 млн. євро.

Китайські інвестиції в АПК, інфраструктуру, енергетику та інші галузі України досягли \$7 млрд. Розміщення виробництв, створення спільних підприємств має належним чином поповнювати, перш за все, бюджет України. Держава зобов'язана зробити належні висновки з відкриття 3ВТ з СС i розробити попереджувальні заходи по максимальному захисту своїх інтересів у торгівлі з більш сильним і більш досвідченим партнером [9].

Теоретико-методологічні підходи до формування та реалізації стратегії розвитку КНР на період до 2050 року. «Правлячий за допомогою чесноти подібний полярній зіриі, яка займає своє місце в оточенні сузір'їв» (Конфуцій). «Стабільність і стабільно поступальний розвиток» стали ключовими словами у програмній промові Сі Цзіньпіна на XIX з'їзді КПК (1824.10.2017p.). При розробці стратегічних планів модернізації китайського соціуму основою продовжують слугувати громадські конфуціанські ідеали, закладені в поняттях «середній достаток» і «велике єднання». Позначено ряд принципів і підходів в економічній політиці, що знайшло відображення в генеральному плані розвитку країни до 2050 р. [10].

По-перше, КНР переходить «від високих темпів зростання до якісного розвитку». За останні п'ять років середні темпи зростання китайської економіки склали 7,2\%, тоді як глобальної - лише $2,6 \%$.

По-друге, держава продовжить підтримувати традиційні заходи економічного розвитку. Інтенсифікується інфраструктурне будівництво. Продовжиться робота 3 ліквідації надлишкових виробничих потужностей, 
боротьба 3 кризою перевиробництва по секторам, а також щодо скорочення боргового навантаження.

По-третє, підтверджено курс на ослаблення контролю держави над економікою. Партія i держава будуть «пробуджувати i оберігати підприємницький дух, заохочувати більше число соціальних суб'єктів до інноваційної і підприємницької діяльності», має значно спроститися інвестиційний режим.

По-четверте, підтверджена політична воля Китаю щодо розвитку економічного співробітництва 3 закордонними партнерами і гарантування прав іноземного капіталу в країні. Робиться наголос на реалізацію ініціативи «Один пояс - Один шлях». Названо три основних етапи розвитку 3 дотриманням принципу стабільності.

Серед основних завдань на ХІІІ-у п'ятирічку (2016-2020рр.): збільшення вдвічі ВВП на душу населення порівняно з 2010р., середнє зростання ВВП не нижче $6,5 \%$ річних, до 2020p. побудувати суспільство «з середнім достатком» [11]. Передбачено реалізувати низку важливих державних науково-технічних проектів. Частка науки в ВВП досягне 2,5\%. Планується створити ряд полюсів економічного зростання [12].

До 2035р. Китай має намір піднятися до рівня країн-лідерів інноваційного типу; скоротиться розрив у рівні доходів; планується ліквідувати затяжну екологічну кризу.

До 2050p. Китай за сукупною національною могутністю та міжнародним впливом увійде до числа країн-лідерів. Основні показники оцінки рівня модернізації Китаю в першій половині XXI ст. представлені в табл. 2. Стратегія i прогнози побудовані на логіці i розрахунках. Їх розробники прагнули врахувати всі чинники розвитку рушійних сил, визначення етапів, постановки проміжних завдань, що ведуть до визначеної мети.

У питанні про особливості стратегічних підходів до розвитку Китаю існують різні погляди аналітиків. Відомий синолог А.П. Дев'ятов, аналізуючи результати роботи XIX з'їзду КПК, і відносячи себе до небополітікам, представив неофіційну історію майбутнього Китаю, «не претендуючи на істину в останній інстанції» і спираючись на розкриті нами таємниці циклів змін, що лежать в основі стратегічного планування концептуальної влади цієї не біблійної цивілізації жовтих людей (Хуа Ся)»[14].

Синологи звертають увагу в своїх дослідженнях на стратагемність китайського мислення i його стратегічних розробок. Стратагемність розглядається як стратегічний план, в якому для супротивника укладена якась пастка або хитрість. Одним з відтінків поняття «стратегемність» одночасно виступають i кмітливість, i винахідливість, i спритність. Китайці класифікували стратагеми за видами і розробили методику застосування кожної залежно від конкретної ситуації. У зв'язку з цим безцінним банком даних виступає «Трактат про 36 Стратагем» Сунь-цзи [15], з якого черпаються 
різні варіанти вирішення проблем у багатьох областях життєдіяльності, включаючи при використанні, наприклад, тих же крипто-валют.

Таблиця 2 - Оцінка рівня модернізації Китаю в першій половині XXIст.

\begin{tabular}{|c|c|c|c|c|c|}
\hline Найменування показників & 2000 & 2020 & 2030 & 2040 & 2050 \\
\hline Частка витрат на НДДКР в ВВП, \% & 1,0 & 2,0 & 2,4 & 3,0 & 3,6 \\
\hline Кількість науковців на 10000 жителів & 5,5 & 12 & 18 & 26 & 39 \\
\hline Кількість патентів на 1 млн. жителів & 20 & 112 & 201 & 359 & 643 \\
\hline Охоплення середньою освітою, \% & 63 & 85 & 89 & 94 & 99 \\
\hline Охоплення вищою освітою, \% & 7,2 & 24 & 34 & 48 & 68 \\
\hline Охоплення ТВ, телевізорів на 1000 чоловік & 293 & 583 & 644 & 711 & 786 \\
\hline $\begin{array}{l}\text { Доступ до Інтернету, користувачів } \\
\text { на } 10000 \text { жителів }\end{array}$ & 178 & 2000 & 3000 & 5000 & 8000 \\
\hline Урбанізація, \% & 36 & 53 & 61 & 71 & 81 \\
\hline Середня тривалість життя, років & 70 & 74 & 77 & 79 & 81 \\
\hline $\begin{array}{l}\text { Середньодушове енергоспоживання, } \\
\text { нафтового еквівалента на людину }\end{array}$ & 868 & 1902 & 2556 & 3435 & 4616 \\
\hline ВВП на душу населення (2000), \$ & 840 & 2451 & 3992 & 6503 & 10593 \\
\hline ВВП на душу населення (ПКС, 2000), \$ & 3920 & 11435 & 15368 & 20653 & 27756 \\
\hline $\begin{array}{l}\text { Частка галузей матеріального виробництва у } \\
\text { ВВП, \% }\end{array}$ & 67 & 45 & 37 & 30 & 24 \\
\hline $\begin{array}{l}\text { Частка зайнятих } \\
\text { виробництві, \% }\end{array}$ & 73 & 49 & 40 & 33 & 27 \\
\hline
\end{tabular}

3 урахуванням особливого стратагемного мислення, насамперед, китайських політиків, для країни бажаним сценарієм стратегічного розвитку може бути досягнення світового лідерства «з тіні». Лідерство розглядається в китайському політикумі не як самоціль, а, швидше за все, як історичний ідеал, здатний згуртувати і мобілізувати китайське суспільство на реалізацію запланованого курсу, темпів і якості розвитку держави. До 100-річчя КНР (1949-2049pр.) країна поза всякими сумнівами займе лідируюче місце на світовій політичній та економічній арені. Забезпечення економічного зростання Китаю гарантується соціальною стабільністю, стабільністю в русі.

\section{Література:}

1. 2027: Страны BRIC обгонят страны G7, а Китай - США. URL: https://22century.ru/cal/bricovertake-g7 (дата обращения 18.04.2014).

2. The World in 2050. The long view: how will the global economic order change by 2050? URL: https://www.pwc.com/gx/en/issues/economy/the-world-in-2050.html

3. Adam Ferguson. An Essay on the History of Civil Society [1767]. CreateSpace Independent Publishing Platform, 2015. 432p.

4. Стиглиц Дж. Ю. Глобализация: тревожные тенденции / пер. с англ. М.: Национальный общественно-научный фонд, 2003. С 29-30.

5. Кобзев А.И. Философия китайского неоконфуцианства. М.: Вост. лит., 2002. 605 с.

6. Дэн Сяопин. Строительство социализма с китайской спецификой. М.: Наука, 1997. 364 с. 
7. Цуй У, Герасимчук В.И. Ресурсосбережение и экономические реформы в Китае // Материалы зонального семинара "Совершенствование хозяйственного механизма ресурсосбережения". Пенза: ПДНТП, 1990. С. 124.

8. Герасимчук В.И., Тьян Т. Удосконалювати механізм торговельно-економічного співробітництва між Україною і Китаєм // Матеріали міжнар. наук.-практ. конф. "Україна Свропейський Союз: проблеми зовнішньоекономічної діяльності та перспективи співробітництва". К.: КДТЕУ, 1995, с. 36.

9. Лисенко В. Зона вільної торгівлі між Україною та Китаєм: всі «за» і «проти». 7 головних питань про те, що принесе Україні ЗВТ з КHР [Електронний ресурс]. URL: http://forbes.net.ua/ua/opinions/1423705-zona-vilnoyi-torgivli-mizh-ukrayinoyu-ta-kitaemvsi-za-i-proti (дата обращения 09.11. 2016).

10. XIX съезд КПК обозначил график развития Китая до 2050 года. URL: http://ekd.me/2017/10/xix-sezd-kpk-oboznachil-grafik-razvitiya-kitaya-do-2050-goda/ (дата обращения: 18.10.2017).

11. Итоги 12-й пятилетки (2011-2015 годы) и перспективы развития экономики КНР до 2020 года / отв. ред. А.В. Островский; сост. П.Б. Каменнов. М.: ИДВ РАН, 2017. 344 с.

12. Манукян Ж., Булатов И. Китай определил задачи в экономике на 2016 год и ХІІІ пятилетку [Электронный ресурc]. URL: https://ria.ru/economy /20160305/ 1385131917.html (дата обращения: 05.03.2016).

13. Муратшина К. Г. «Китай-2050»: специфика формирования стратегии // Известия Уральского государственного университета. 2010. № 3(80). С. 85-92.

14. Девятов А. Китай и перемены. Небополитическая оценка XIX съезда КПК [Электронный pecypc]. URL: http://www.cetrasia.ru/newsA.php?st=1508740020 (дата обращения: 23.10.2017).

15. Сунь-цзы. Трактат о военном искусстве // Искусство стратегии: древнекитайские трактаты / пер. с кит., предисл. и коммент. Н. И. Конрада. М.: Эксмо; СПб.: Мидгард, 2006. $528 \mathrm{c}$. 